\title{
ANALISIS KEBUTUHAN DIKLAT (AKD) PADA BALAI DIKLAT KEAGAMAAN DENPASAR TAHUN 2018
}

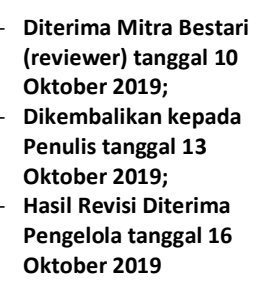

\section{Wayan Iwantara}

Widyaiswara Balai Diklat Keagamaan Denpasar, iwantwyn@gmail.com

\begin{abstract}
Abstrak
Penelitian ini bertujuan untuk menentukan jenis diklat yang dibutuhkan untuk pengembangan kompetensi Aparatur Sipil Negara (ASN) di wilayah kerja Balai Diklat Keagamaan Denpasar berdasarkan hasil Analisis Kebutuhan Diklat (AKD) Tahun 2018. Sampel dan populasi penelitian ini adalah sebanyak 1120 responden yang berasal dari guru, pengawas, penyuluh, penghulu, kepala madrasah, pejabat struktural eselon IV di lingkungan Kementerian Agama Provinsi Bali, NTB dan NTT. Data yang diperoleh yaitu data jenis diklat yang dibutuhkan di wilayah Kerja Balai Diklat Keagamaan Denpasar. Teknik pengumpulan data yang digunakan yaitu teknik angket.- Instrumennya berupa angket pemetaan kompetensi dan kebutuhan diklat. Teknik analisis datanya yaitu mencari persentase kebutuhan untuk masing-masing jenis diklat. Analisis lanjutnya yaitu penentuan 10 diklat prioritas pada masing-masing jenis diklat. Kesimpulan penelitian adalah jenis diklat yang dibutuhkan ASN di wilayah Kerja Balai Diklat Keagamaan Denpasar berdasarkan hasil Analisis Kebutuhan Diklat Tahun 2018, yaitu: Diklat Substantif pendidikan sebesar 75,14\%, Diklat Teknis Substantif Keagamaan sebesar 9,19\%, Diklat Fungsional Pendidikan sebesar 11,85\% dan Diklat Fungsional Keagamaan sebesar 4,32\%. Rekomendasi-penelitian ini agar AKD ditindaklanjuti oleh Balai Diklat Keagamaan Denpasar dalam bentuk penyusunan rencana program diklat Tahun 2019 dengan mempertimbangkan skala prioritas.
\end{abstract}

\section{Kata Kunci : Analisis Kebutuhan Diklat, Kompetensi, Aparatur Sipil Negara}

\section{A. PENDAHULUAN}

\section{Latar Belakang}

Diklat adalah salah satu rencana program yang dibuat untuk meningkatkan kompetensi dan kapabilitas Sumber Daya Manusia (SDM) dalam menjalankan tugas jabatannya dalam kaitannya untuk mendukung pencapaian tujuan organisasi. Peraturan Pemerintah No. 101 Tahun 2000 tentang Pendidikan dan Pelatihan Jabatan
Pegawai Negeri Sipil menyebutkan diklat adalah proses penyelenggaraan belajar mengajar dalam rangka meningkatkan kemampuan Pegawai Negeri Sipil. Diklat adalah bentuk pengembangan diri yang dapat dilakukan untuk meningkatkan kompetensi Aparatur Sipil Negara dalam menjalankan tugasnya. Diklat mempunyai posisi yang sangat strategis untuk mengembangkan kompetensi ASN. Melalui diklat, ASN akan 
digembleng kompetensinya baik sikap, pengetahuan maupun ketrampilannya sehingga diharapkan dapat melaksanakan tugas secara lebih profesional.

Menurut PMA No. 75 Tahun 2015 tentang penyelenggaraan diklat, disebutkan bahwa diklat adalah penyelenggaraan pembelajaran dan pelatihan dalam rangka mengembangkan kompetensi pegawai sesuai persyaratan jabatan masing-masing pada Kementerian Agama yang dilaksanakan paling sedikit 40 (empat puluh) jam pelajaran, dengan durasi tiap jam pelajaran adalah 45 menit.

Pengembangan kompetensi yang dimaksud di sini mencakup pengembangan kompetensi sikap, pengetahuan dan ketrampilan. Pada pelaksanaan diklat, komposisi pembekalan pengetahuan dan ketrampilan dilakukan secara seimbang. Selain diberikan pembekalan secara teoritik peserta juga diberikan kiat-kiat bagaimana menerapkan pengetahuan yang telah dan baru dimilikinya serta solusi apa yang bisa diterapkan untuk mempermudah dalam pelaksanaan tugas jabatannya. Pelaksanaan diklat juga menanamkan pengembangan kompetensi sikap. Selama pelaksanaan diklat peserta selalu diharapkan untuk berprilaku sesuai dengan norma dan bisa bekerja dengan baik dengan panitia dan widyaiswara, karena sikap juga menjadi poin penting dalam penentuan kelulusan peserta. Tiga ranah yang menjadi poin penilaian ini pada akhirnya diharapkan menghasilkan output diklat yang berkualitas dan memberikan dampak yang signifikan bagi pencapaian tujuan organisasi tempat peserta bertugas.

Mengingat pentingnya pelaksanaan diklat untuk peningkatan kompetensi ASN dan mendukung pencapaian tujuan organisasi, maka perencanaan diklat menjadi hal yang sangat penting untuk dilakukan. Melalui perencanaan diklat diharapkan menghasilkan perencanaan diklat berbasis kebutuhan, artinya diklat-diklat yang dibutuhkan untuk meningkatkan kompetensi dan kapabilitas ASN dalam melaksanakan tugas jabatannya sehingga mampu meningkatkan kinerja ASN dalam organisasinya.

Pada kenyataannya perencanaan diklat di Balai Diklat Keagamaan Denpasar pada tahun 2016 dan tahun sebelumnya masih menekankan pada penggunaan data hasil rapat koordinasi di wilayah Balai Diklat Keagamaan Denpasar dan data beberapa proposal diklat yang masuk ke Balai Diklat Keagamaan Denpasar. Data yang didapat dari rapat koordinasi ini masih sangat minimal secara kuantitas maupun kualitas karena yang diundang adalah perwakilan dari daerah untuk mengisi daftar isian diklat yang dibutuhkan ASN di wilayah kerja. Data hasil rapat koordinasi ini kurang mencerminkan data yang sesungguhnya dibutuhkan karena 
yang mengisi bukan ASN yang bersangkutan tetapi diwakilkan. Dengan demikian diklatdiklat yang dimunculkan sebagai rencana diklat hanya berdasarkan pemikiran pejabat yang mewakili bukan murni berdasarkan kebutuhan yang diisi oleh user. Organisasi yang menyelenggarakan diklat tidak berdasarkan identifikasi kebutuhan diklat ini akan mengalami resiko yaitu, tidak efektifnya pelaksanaan diklat. Hal ini dikarenakan diklat yang dikembangkan dan dilaksanakan belum tentu dibutuhkan untuk mengatasi permasalahan ASN di tempat kerjanya.

Untuk itu Balai Diklat Keagamaan Denpasar melaksanakan Analisis Kebutuhan Diklat (AKD) sebagai salah satu solusi penyelenggaraan diklat yang efektif, efisien dan berkualitas. AKD merupakan dasar dari perencanaan program diklat berbasis kebutuhan. Papu (2002) menyatakan Analisis Kebutuhan Diklat yaitu, proses berkelanjutan pengumpulan data untuk menentukan jenis diklat yang dibutuhkan sehingga diklat dapat dikembangkan untuk mencapai tujuan organisasi. AKD sangat penting dilakukan untuk memetakan jenis diklat yang dibutuhkan untuk meningkatkan kompetensi dan kapabilitas ASN dalam melaksanakan tugas jabatannya. AKD sangat bermanfaat secara individual maupun secara organisasi. Secara individual, AKD sangat bermanfaat untuk mengetahui kompetensi yang harus ditingkatkan untuk meningkatkan kinerja
ASN, sedangkan secara organisasi, pelaksanaan AKD dapat mendukung pencapaian tujuan organisasi. Menurut Papu (2002) tanpa analisis kebutuhan yang sungguh-sungguh maka dapat dipastikan bahwa program diklat yang dirancang hanya akan berlangsung sukses di ruang kelas atau tempat pelaksanaan diklat saja. Pelaksanaan diklat mungkin berjalan dengan sangat baik, tetapi pada saat peserta sudah kembali ke tempat kerja masing-masing mereka menjadi tidak tahu atau bingung bagaimana menerapkan apa yang telah mereka pelajari. AKD pada akhirnya diharapkan dapat mengidentifikasi jenis-jenis diklat yang dibutuhkan dan meningkatkan kinerja ASN.

\section{Rumusan Masalah}

Berdasarkan latar belakang di atas maka dapat dirumuskan masalah, yaitu "Jenis diklat apa yang dibutuhkan untuk pengembangan kompetensi ASN di wilayah kerja Balai Diklat Keagamaan Denpasar berdasarkan hasil Analisis Kebutuhan Diklat Tahun 2018?"

\section{Tujuan Penelitian}

Berdasarkan rumusan masalah di atas maka dapat dirumuskan tujuan penelitian, yaitu untuk menentukan jenis diklat yang dibutuhkan untuk pengembangan kompetensi ASN di wilayah kerja Balai Diklat 
Keagamaan Denpasar berdasarkan hasil Analisis Kebutuhan Diklat Tahun 2018.

\section{Manfaat Penelitian}

a. Bagi User

Hasil Analisis Kebutuhan Diklat ini dapat digunakan oleh user di wilayah kerja Balai Diklat Keagamaan Denpasar untuk memetakan kompetensinya yang masih kurang dan perlu ditingkatkan dalam rangka peningkatan kinerja user

b. Bagi Organisasi User

Hasil Analisis Kebutuhan Diklat dapat digunakan oleh organisasi user untuk memetakan kompetensi ASNnya dan sebagai bahan untuk perencanaan program untuk pembinaan dan pengembangan kompetensi ASN di wilayah kerjanya.

c. Bagi Balai Diklat Keagamaan Denpasar Hasil Analisis Kebutuhan Diklat Tahun 2018 ini dapat digunakan sebagai rujukan oleh pejabat Balai Diklat Keagamaan Denpasar dalam merencanakan program kegiatan diklat di wilayah kerja Balai Diklat Keagamaan Denpasar Tahun 2019.

\section{B. KAJIAN TEORITIK}

Definisi Analisis Kebutuhan Diklat

Menzel dan Messina (2011:22)

menyatakan Training Needs Analysis

(TNA) atau yang diistilahkan dengan

Analisis Kebutuhan Diklat (AKD) merupakan tahap kritis pertama dalam siklus pelatihan. Dengan AKD, manajemen mengidentifikasi kesenjangan yang ada serta kekuatan dan kelemahan dalam proses yang menghambat program pelatihan. AKD memiliki kaitan yang erat dengan perencanaan diklat, yaitu perencanaan yang paling baik didahului dengan mengidentifikasikan masalah atau kebutuhan. Hasil dari analisis kebutuhan diklat merupakan masukan utama dalam proses perencanaan diklat.

Bee (PKP2A I LAN, 2006) menyatakan AKD adalah suatu proses yang sistematis dalam mengidentifikasi ketimpangan antara sasaran dengan keadaan nyata atau diskrepansi antara standar kinerja dan kinerja nyata yang penyelesaiannya melalui pelatihan analisis kebutuhan pelatihan dan pengembangan yang sangat penting, rumit dan sulit. Hariadja (2007) mengungkapkan AKD sangat penting digunakan sebagai landasan penentuan pelatihan yang tepat, sehingga jika pelatihan tidak sesuai dengan kebutuhan, selain tidak meningkatkan kemampuan organisasi juga akan menghabiskan banyak biaya. Selanjutnya dikatakan rumit dan sulit sebab perlu mendiagnosis kompetensi organisasi pada saat ini dan kompetensi yang dibutuhkan sesuai dengan kecenderungan perubahan situasi 
lingkungan yang sedang dihadapi dan yang akan dihadapi pada masa yang akan datang. Menurut Barbazette (2006:5), analisis kebutuhan pelatihan dilakukan untuk meningkatkan kinerja atau menutupi kinerja yang tidak memenuhi standar.

$$
\text { Mangkunegara }
$$

mengungkapkan, penentuan kebutuhan akan pelatihan harus dilakukan melalui analisis baik ditingkat organisasi, jabatan/tugas/pekerjaan, maupun individu.

1. Analisis tingkat organisasi untuk mengetahui dibagian mana dalam organisasi yang memerlukan pelatihan;

2. Analisis jabatan/tugas/pekerjaan untuk mengidentifikasi isi pelatihan yang dibutuhkan, artinya apa yang harus dilakukan pegawai supaya dapat melaksanakan tugas sesuai jabatan yang kompeten;

3. Analisis ditingkat individu untuk mengidentifikasi karakteristik pegawai, artinya kemampuan dan keterampilan apa yang seharusnya diperlukan untuk melaksanakan jabatan.

\section{Tujuan Analisis Kebutuhan Diklat (AKD)}

Bee (PKP2A I LAN, 2006), mendifinisikan tujuan diklat berdasarkan tiga tahap analisis kebutuhan yaitu :

1. Mengindentifikasi adanya kebutuhan untuk meningkatkan kinerja atau kompetensi sumber daya manusia organisasi.;

2. Menentukan kebutuhan diklat tersebut secara tepat;

3. Menentukan jenis diklat yang dapat memenuhi kebutuhan diklat

AKD sangat diperlukan untuk mengidentifikasi kompetensi mana yang masih harus ditingkatkan untuk mendukung peningkatan kinerja ASN dalam melaksanakan tupoksinya. Peningkatan kompetensi ASN ini dapat dilakukan melalui pelaksanaan diklat. Dengan demikian tujuan akhir AKD adalah untuk menentukan jenis diklat sesuai dengan kebutuhan peningkatan kompetensi ASN.

\section{Manfaat Analisis Kebutuhan Diklat (AKD)}

Manfaat analisis kebutuhan diklat sendiri menurut Miller dan Osinski (Kaswan, 2011), analisis kebutuhan dapat membantu :

1. Kompetensi dan kinerja tim kerja.

2. Memecahkan masalah atau isu produktivitas. 
3. Mempersiapkan dan merespon kebutuhan masa depan di dalam organisasi atau kewajiban pekerjaan.

Bee (PKP2A I LAN, 2006) menyebutkan, manfaat analisis kebutuhan pelatihan antara lain:

a. Program-program diklat yang disusun sesuai dengan kebutuhan organisasi, jabatan maupun individu setiap pegawai;

b. Menjaga dan meningkatkan motivasi peserta dalam mengikuti pelatihan, karena program pelatihan yang diikuti sesuai dengan kebutuhannya. Dengan demikian akan mencapai efektifitas pencapaian tujuan pelatihan;

c. Efisiensi biaya organisasi karena pelatihan yang dilaksanakan sesuai dengan kebutuhan organisasi. Jadi biaya yang tidak sedikit yang dikeluarkan untuk pelatihan tidaklah sia-sia;

d. Memahami penyebab timbulnya masalah dalam organisasi, karena pelaksanaan penilaian kebutuhan yang tepat dan efektif, tidak saja akan menemukan masalah-masalah yang ditimbulkan oleh diskrepansi kompetensi pegawai/pekerja

Analisis Kebutuhan Diklat memberikan manfaat yang sangat signifikan bagi pelaksanaan diklat. Hal ini disebabkan oleh pelaksanaan diklat yang sudah berbasis kebutuhan. Kondisi inilah yang meningkatkan motivasi peserta untuk mengikuti diklat karena diklat yang diselenggarakan sangat diperlukan materinya untuk meningkat kompetensinya yang masih kurang.

\section{Tahapan Analisis Kebutuhan Diklat (AKD)}

Tahapan Analisis Kebutuhan Diklat menurut Tees et al (1987) dapat disajikan seperti Gambar 1.

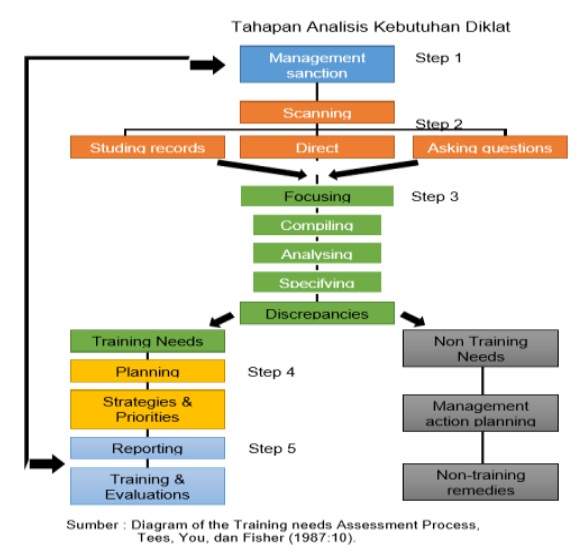

Gambar 1. Tahapan Analisis Kebutuhan

Diklat

Tees, David W., You, Nicholas., dan Fisher, Fred., (1987) membagi TNA dalam 5 (lima) proses penting yaitu :

a. Tahap 1 : Persetujuan dan kesiapan manajemen dalam melakukan analisis kebutuhan. Proses TNA dimulai ketika manajemen terutama pimpinan organisasi mengizinkan pelaksanaan penilaian kebutuhan yang sistematis dalam menemukan target yang tepat 
untuk pelatihan. Inisiasi TNA harus didahului dengan perencanaan yang rinci dan penjadwalan;

b. Tahap 2 : Membaca lingkungan kerja organisasi. Tahapan ini melihat permasalahan yang terjadi pada pelaksanaan pekerjaan, tim kerja, departemen, atau organisasi. Tiga bentuk umum dalam pembacaan lingkungan organisasi dengan mempelajari catatan tertulis/telaah dokumen organisasi, mengajukan pertanyaan/kuesioner kepada pegawai tentang kinerja atau kesenjangan lain yang dicari, dan mengamati kinerja yang terjadi;

c. Tahap 3 : Memfokuskan pada kesenjangan dan kebutuhan diklat. Tahapan selanjutnya adalah memfokuskan permasalahan yang didapatkan sebelumnya dengan menghimpun semua permasalahan, menganalisa dan menspesifikasikan jenis kesenjangan yang dapat diselesaikan melalui kebutuhan diklat atau kebutuhan non diklat;

d. Tahap 4 : Merencanakan untuk pelaksanaan diklat. Setelah menetapkan kebutuhan diklat, selanjutnya merancang pelaksanaan diklat. Proses ini bisa saja menggunakan tenaga konsultan/tenaga ahli dalam memudahkan penentuan model dan jenis pelatihan yang akan digunakan;

e. Tahap 5 : Pelaporan Manajemen. Langkah terakhir dalam penilaian kebutuhan pelatihan adalah untuk mempersiapkan laporan kepada manajemen.

\section{METODE PENELITIAN} Populasi dan Sampel

Populasi penelitian ini yaitu sebanyak 1120 responden yang berasal dari guru, pengawas, penyuluh, penghulu, kepala madrasah, pejabat struktural eselon IV di lingkungan Kementerian Agama Provinsi Bali, NTB dan NTT. Seluruh populasi ini menjadi sampel, sehingga jumlah sampelnya sebanyak 1120 orang.

\section{Tempat dan Waktu Penelitian}

Penelitian ini dilaksanakan dari bulan Nopember sampai Desember 2018 bertempat di 28 Kantor Kementerian Agama Kabupaten/Kota di Provinsi Bali, Nusa Tenggara Barat dan Nusa Tenggara Timur.

\section{Teknik Pengumpulan Data}

Teknik pengumpulan data yang digunakan dalam penelitian ini yaitu teknik angket. Instrumen yang digunakan yaitu angket pemetaan kompetensi dan kebutuhan diklat. Ada dua angket yang digunakan dalam penelitian ini. Angket 
pertama untuk melihat pemetaan kompetensi dan angket kedua untuk melihat kebutuhan diklat pada masingmasing jabatan untuk mengatasi gap kompetensi Aparatur Sipil Negara. Pelaksanaan Analisis Kebutuhan Diklat dilakukan secara Focus Group Discussion (FGD), yaitu 40 orang responden dikumpulkan pada suatu ruangan di masing-masing Kantor Kementerian Agama Kabupaten/Kota.

\section{Teknik Analisis Data}

Data kebutuhan diklat disusun berdasarkan data pada masing-masing Kantor Kementerian Agama Kabupaten/Kota. Selanjutnya dilakukan rekapitulasi seluruh data Kantor Kementerian Agama Kabupaten/Kota di wilayah Provinsi Bali, Nusa Tenggara Barat dan Nusa Tenggara Timur. Data kemudian dikelompokkan sesuai dengan jenis diklat. Jenis diklat dalam penelitian ini dikelompokkan menjadi 4 , yaitu a) Diklat Teknis Substantif Pendidikan, b) Diklat Teknis Substantif Keagamaan, c) Diklat Fungsional Pendidikan dan d) Diklat Fungsional Keagamaan. Data masingmasing jenis diklat kemudian dianalisis dengan melihat persentase kebutuhannya yaitu

Persentase Kebutuhan Diklat

$=\frac{\text { Jumlah Diklat pada Tiap Jenis Diklat }}{\text { Jumlah Total Diklat }}$
Analisis selanjutnya, yaitu menganalisis 10 diklat peringkat teratas sebagai prioritas diklat pada masingmasing jenis diklat di wilayah Kementerian Agama Provinsi Bali, Nusa Tenggara Barat dan Nusa Tenggara Timur. Data dianalisis dengan tabulasi sederhana yaitu dengan melihat hasil perbandingan antara rata-rata prioritas data diklat yang disi dengan jumlah sampel yang mengisi data itu. Secara sederhana dapat dirumuskan

$$
a=\frac{\text { Rata-rata }}{\text { Jumlah Data }}
$$

\section{Keterangan :}

Semakin kecil nilai a, maka semakin menjadi prioritas diklat itu untuk dilaksanakan demikian juga dengan sebaliknya

\section{HASIL PENELITIAN DAN PEMBAHASAN} Hasil Penelitian

Pelaksanaan Analisis Kebutuhan Diklat di Wilayah Kerja Balai Diklat Keagamaan Denpasar yang dilakukan di 28 kantor Kementerian Agama Kabupaten/Kota se Provinsi Bali, NTB dan NTT. Seluruh data ini direkap kemudian dikelompokkan menjadi 4 jenis diklat, yaitu a) Diklat Teknis Substantif Pendidikan, b) Diklat Teknis Substantif Keagamaan, c) Diklat Fungsional Pendidikan dan d) Diklat Fungsional Keagamaan. Data pada masing-masing 
jenis diklat ini kemudian dianalisis dengan mempertimbangkan 10 jenis diklat peringkat teratas. Data Kebutuhan Diklat ASN di Wilayah Kerja Balai Diklat Keagamaan Denpasar dapat disajikan seperti Gambar 1 di bawah ini.

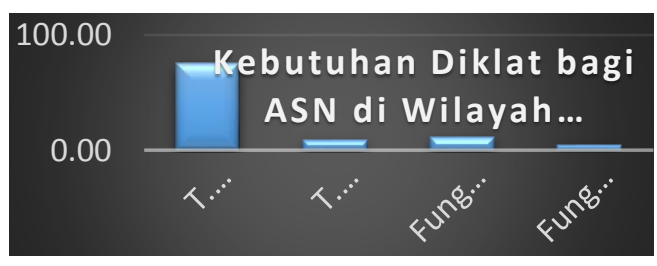

Gambar 1. Kebutuhan Diklat bagi ASN di Wilayah Kerja

Balai Diklat Keagamaan Denpasar
Berdasarkan Gambar 1 di atas, kebutuhan Diklat Teknis Substantif Pendidikan bagi ASN di wilayah kerja Balai Diklat Keagamaan Denpasar sebesar 75,14\% (139 jenis diklat), Diklat Teknis Substantif Keagamaan sebesar 9,19\% (17 jenis diklat), Diklat Fungsional Pendidikan sebesar 11,85\% (21 jenis diklat) dan Diklat Fungsional Keagamaan sebesar $4,32 \%$ ( 8 jenis diklat).

Sepuluh Diklat Teknis Substantif Pendidikan peringkat teratas yang sangat dibutuhkan ASN di wilayah kerja Balai Diklat Keagamaan Denpasar seperti tertera pada Tabel 1 .

\begin{tabular}{|c|l|c|c|}
\hline No & $\begin{array}{l}\text { Diklat Teknis Substantif Pendidikan yang banyak } \\
\text { dibutuhkan oleh ASN di Wilayah Kerja Balai Diklat } \\
\text { Keagamaan Denpasar }\end{array}$ & Nilai & Prioritas \\
\hline 1 & $\begin{array}{l}\text { Diklat Teknis Substantif Penelitian Tindakan Kelas } \\
\text { (PTK) }\end{array}$ & 0.029 & 1 \\
\hline 2 & \begin{tabular}{l} 
Diklat Teknis Substantif Model-model Pembelajaran \\
\hline 3
\end{tabular} & 0.033 & 2 \\
\hline 4 & $\begin{array}{l}\text { Diklat Teknis Substantif Penilaian Pembelajaran } \\
\text { Multat Teknis Substantif Media Pembelajaran Berbasis }\end{array}$ & 0.038 & 0.040 \\
\hline 5 & $\begin{array}{l}\text { Diklat Teknis Substantif Penyusunan Rencana } \\
\text { Pembelajaran (RPP) }\end{array}$ & 0.042 & 5 \\
\hline 6 & Diklat Teknis Substantif Penyusunan Bahan Ajar & 0.044 & 6 \\
\hline 7 & $\begin{array}{l}\text { Diklat Teknis Substantif Pendekatan Saintifik Dalam } \\
\text { Pembelajaran }\end{array}$ & 0.051 & 7 \\
\hline 8 & $\begin{array}{l}\text { Diklat Teknis Substantif Pengelolaan Penilaian Hasil } \\
\text { Pembelajaran }\end{array}$ & 0.054 & 8 \\
\hline 9 & Diklat Teknis Substantif Pembelajaran Tematik RA & 0.060 & 9 \\
\hline 10 & Diklat Teknis Substantif PKG-PKB & 0.070 & 10 \\
\hline
\end{tabular}

Tabel 1. Diklat Teknis Substantif Pendidikan yang banyak dibutuhkan oleh ASN di Wilayah Kerja Balai Diklat Keagamaan Denpasar 
Berdasarkan Tabel 1, diklat teknis substantif pendidikan yang banyak dibutuhkan untuk peningkatan kompetensi ASN di wilayah kerja yaitu diklat untuk pengembangan kompetensi guru. Diklat Teknis Substantif PTK menduduki peringkat pertama dengan skor 0,029, dilanjutkan dengan Diklat Teknis Substantif Model-model Pembelajaran dengan skor 0,033, Diklat Teknis Substantif Penilaian Pembelajaran dengan skor, 0,038, Diklat Teknis Substantif Media Pembelajaran Berbasis Multimedia dengan skor 0,04, Diklat Teknis Substantif Penyusunan RPP dengan skor 0,042, Diklat Teknis Substantif Penyusunan Bahan Ajar dengan skor 0,04, Diklat Teknis Substantif Pendekatan Saintifik dalam Pembelajaran dengan skor 0,051, Diklat Teknis Substantif Pengelolaan Penilaian Hasil Pembelajaran dengan skor 0,054, Diklat Teknis Substantif Pembelajaran Tematik RA dengan skor 0,060. Diklat Teknis Substantif PKG-PKB menempati peringkat 10 dengan skor 0,07 .

Selain Diklat Teknis Substantif Pendidikan, ASN di Wilayah Kerja Balai Diklat Keagamaan Denpasar juga membutuhkan Diklat Teknis Substantif Keagamaan. Jenis Diklat Teknis Substantif Keagamaan yang banyak dibutuhkan ASN di Wilayah Kerja Balai Diklat Keagamaan Denpasar dapat disajikan seperti Tabel 2.

\begin{tabular}{|c|l|c|c|}
\hline No & $\begin{array}{c}\text { Diklat Teknis Substantif Keagamaan yang Banyak } \\
\text { Dibutuhkan ASN di Wilayah Kerja Balai Diklat } \\
\text { Keagamaan Denpasar }\end{array}$ & Nilai & $\begin{array}{c}\text { Priori } \\
\text { Tas }\end{array}$ \\
\hline 1 & \begin{tabular}{l} 
Diklat Teknis Substantif Karya Ilmiah Penyuluh Agama \\
\hline 2
\end{tabular} & 0.084 & 1 \\
\hline 3 & $\begin{array}{l}\text { Diklat Teknis Substantif Penyuluh Agama Non PNS } \\
\text { Agama }\end{array}$ & 0.094 & 2 \\
\hline 4 & Diklat Teknis Substantif Kerukunan Umat Beragama & 0.119 & 4 \\
\hline 5 & Diklat Teknis Substantif Penilai Angka Kredit Penghulu & 0.142 & 5 \\
\hline 6 & Diklat Teknis Substantif Keluarga sakinah Kepala KUA & 0.216 & 6 \\
\hline 7 & Diklat Teknis Substantif Karya ilmiah Penghulu & 0.226 & 7 \\
\hline 8 & Diklat Teknis Substantif Petugas Penyelenggaraan Haji & 0.261 & 8 \\
\hline 9 & Diklat Teknis Substantif Pembina Kemasjidan & 0.273 & 9 \\
\hline 10 & Diklat Teknis Substantif Pembina Nazir Wakaf & 0.289 & 10 \\
\hline
\end{tabular}

Tabel 2. Diklat Teknis Substantif Keagamaan yang banyak dibutuhkan oleh ASN di Wilayah Kerja Balai Diklat Keagamaan Denpasar 
Berdasarkan Tabel 2, Diklat Teknis

Substantif Keagamaan yang paling banyak dibutuhkan oleh ASN di Wilayah Kerja Balai Diklat Keagamaan Denpasar, yaitu Diklat Teknis Substantif Karya Ilmiah Penyuluh Agama dengan skor 0,084. Diklat lainnya yang dibutuhkan yaitu Diklat Teknis Substantif Penyuluh Agama Non PNS dengan skor 0,094, Diklat Teknis Substantif Penilai Angka Kredit Penyuluh Agama dengan skor 0,113, Diklat Teknis Substantif Kerukunan Umat Beragama dengan skor 0,119, Diklat Teknis Substantif Angka Kredit Penghulu dengan skor 0,142, Diklat Teknis Substantif Keluarga Sakinah Kepala KUA 0,216, Diklat Teknis Substantif Karya Ilmiah
Penghulu dengan skor 0,226, Diklat Teknis Substantif Petugas Penyelenggara Haji dengan skor 0,261. Diklat Teknis Substantif Pembina Kemasjidan dengan skor 0,273. Diklat Teknis Substantif Pembina Nasir Wakaf menempati peringkat 10 dengan skor 0,289.

Pelaksanaan diklat juga diarahkan pada diklat pembentukan jabatan dan pengembangan kompetensi jabatan fungsional tertentu sesuai jenjangnya. Jenis Diklat Fungsional Pendidikan yang banyak dibutuhkan ASN di Wilayah Kerja Balai Diklat Keagamaan Denpasar dapat disajikan seperti Tabel 3.

\begin{tabular}{|c|l|c|c|}
\hline No & $\begin{array}{c}\text { Diklat Fungsional Pendidikan yang Banyak Dibutuhkan } \\
\text { ASN di Wilayah Kerja Balai Diklat Keagamaan Denpasar }\end{array}$ & Nilai & Prioritas \\
\hline 1 & Diklat Fungsional Calon Kepala RA & 0.135 & 1 \\
\hline 2 & Diklat Fungsional Calon Kepala Madrasah & 0.160 & 2 \\
\hline 3 & Diklat Fungsional Pengawas Madya & 0.181 & 3 \\
\hline 4 & Diklat Fungsional Calon Pengawas Pendidikan Agama & 0.249 & 4 \\
\hline 5 & Diklat Fungsional Pengawas Muda & 0.255 & 5 \\
\hline 6 & Diklat Fungsional Guru Muda & 0.311 & 6 \\
\hline 7 & Diklat Fungsional Guru Madya & 0.345 & 7 \\
\hline 8 & Diklat Fungsional Guru Pertama & 0.347 & 8 \\
\hline 9 & Diklat Fungsional Calon Pengawas Madrasah & 0.352 & 9 \\
\hline 10 & Diklat Fungsional Calon Kepala Perpustakaan Madrasah & 0.509 & 10 \\
\hline
\end{tabular}

Tabel 3. Diklat Fungsional Pendidikan yang banyak dibutuhkan oleh ASN di Wilayah Kerja Balai Diklat Keagamaan Denpasar

Berdasarkan Tabel 3 terlihat diklat fungsional pendidikan yang banyak dibutuhkan ASN di wilayah kerja Balai
Diklat Keagamaan Denpasar yaitu Diklat Fungsional Calon Kepala RA dengan skor 0,135, kemudian dilanjutkan dengan 
Diklat Fungsional Calon Kepala Madrasah dengan skor 0,160. Diklat lain yang ada di peringkat di bawahnya yaitu Diklat Fungsional Pengawas Madya dengan skor 0,181, Diklat Fungsional Calon Pengawas Pendidikan Agama dengan skor 0,249, Diklat Fungsional Guru Pengawas Muda dengan skor 0,255, Diklat Fungsional Guru Muda dengan skor 0,311, Diklat Fungsional Guru Madya dengan skor 0,345, Diklat Fungsional Guru Pertama dengan skor 0,347, Diklat Fungsional
Calon Pengawas Madrasah dengan skor 0,352, dan Diklat Fungsional Calon Kepala Perpustakaan dengan skor 0,509.

Diklat pembentukan jabatan dan pengembangan kompetensi Jabatan Fungsional di bidang keagamaan juga menjadi prioritas untuk dilaksanakan. Jenis Diklat Fungsional Keagamaan yang banyak dibutuhkan ASN di Wilayah Kerja Balai Diklat Keagamaan Denpasar dapat disajikan seperti Tabel 4.

\begin{tabular}{|c|l|c|c|}
\hline No & $\begin{array}{c}\text { Diklat Fungsional Keagamaan yang banyak } \\
\text { dibutuhkan ASN di Wilayah Kerja Balai Diklat } \\
\text { Keagamaan Denpasar }\end{array}$ & Nilai & Prioritas \\
\hline 1 & Diklat Fungsional Penyuluh Agama Madya & 0.154 & 1 \\
\hline 2 & Diklat Fungsional Penyuluh Agama Muda & 0.165 & 2 \\
\hline 3 & Diklat Fungsional Penghulu Muda & 0.173 & 3 \\
\hline 4 & Diklat Fungsional Penyuluh Agama Pertama & 0.227 & 4 \\
\hline 5 & Diklat Fungsional Calon Kepala KUA & 0.272 & 5 \\
\hline 6 & Diklat Fungsional Calon Penghulu & 0.302 & 6 \\
\hline 7 & Diklat Fungsional Penghulu Pertama & 0.334 & 7 \\
\hline 8 & Diklat Fungsional Penghulu Madya & 0.483 & 8 \\
\hline
\end{tabular}

Tabel 4. Diklat Fungsional Keagamaan yang banyak dibutuhkan oleh ASN di Wilayah Kerja Balai Diklat Keagamaan Denpasar

Tabel 4 memperlihatkan Diklat Fungsional Penyuluh Agama Madya dengan skor 0,154 menjadi prioritas utama dilaksanakan karena ada di peringkat pertama. Diklat-diklat fungsional keagamaan lain yang menjadi prioritas untuk dilaksanakan yaitu : Diklat Penyuluh Agama Muda dengan skor 0,165, Diklat Fungsional Penghulu Muda dengan skor 0,173, Diklat Fungsional Penyuluh
Agama Pertama dengan skor 0,227, Diklat Fungsional Calon Kepala KUA dengan skor 0,272, Diklat Fungsional Calon Penghulu dengan skor 0,302, Diklat Fungsional Penghulu Pertama dengan skor 0,334 dan Diklat Fungsional Penghulu Madya dengan skor 0,483 . 


\section{Pembahasan}

\section{Pelaksanaan Analisis Kebutuhan}

Diklat di Wilayah Kerja Balai Diklat Keagamaan Denpasar sudah diawali dengan tahap persetujuan dan kesiapan manajemen dalam melaksanakan AKD. Kepala Balai Diklat Keagamaan Denpasar sudah mengijinkan bahkan sangat mendukung pelaksanaan AKD karena AKD ini adalah langkah awal untuk mendukung penyelenggaraan diklat yang efektif. Hal ini didukung oleh kesiapan Balai Diklat Keagamaan Denpasar dari sisi anggaran, tim AKD yang akan diterjunkan ke wilayah kerja dan instrumen yang perlu disiapkan untuk kelancaran pelaksanaan AKD. Pada tahap kedua, yaitu membaca lingkungan kerja organisasi di wilayah kerja dilakukan dengan melihat tingkat kompetensi ASN di wilayah kerja. Hal ini dilakukan dengan menyebarkan angket ke wilayah kerja Balai Diklat Keagamaan Denpasar yang dalam hal ini hanya 28 sampel Kantor Kementerian Agama Kabupaten/Kota di Provinsi Bali, NTB dan NTT. Tahap ketiga, yaitu memfokuskan pada kesenjangan dan kebutuhan diklat. Hal ini dilakukan dengan mengidentifikasi kompetensi yang sudah dimiliki ASN dan kompetensi apa yang masih harus ditingkatkan. Tahap Keempat, yaitu perencanaan untuk pelaksanaan diklat. Hal ini dilakukan dengan merencanakan diklatdiklat yang menjadi skala prioritas untuk dilaksanakan berdasarkan penentuan diklat yang tepat untuk mengatasi gap kompetensi ASN dan diklat-diklat mana yang lebih mendesak untuk dilaksanakan sesuai kebutuhan user. Tahap kelima, pelaporan ke manajemen. Tahap terakhir dari pelaksanaan AKD yaitu melaporkan hasil pelaksanaan AKD kepada pimpinan.

Berdasarkan hasil pengolahan data analisis kebutuhan diklat untuk diklat teknis Substantif pendidikan, rangking 1 sampai dengan 10 didominasi oleh diklat untuk pengembangan kompetensi guru. Diantara beberapa diklat tentang peningkatan kompetensi guru yang menjadi kebutuhan prioritas guru untuk dilaksanakan diantaranya, yaitu Diklat Teknis Substantif Penelitian Tindakan Kelas. Berdasarkan hasil angket terbuka, banyak guru menganggap diklat ini penting untuk menghasilkan laporan PTK yang dapat digunakan untuk mendukung kenaikan pangkat dan jabatan guru. Selain itu diklat lain yang menjadi prioritas untuk dilaksanakan, yaitu diklat pengembangan kompetensi pedagogik guru diantaranya Diklat Teknis Substantif Modelmodel Pembelajaran, Penilaian Pembelajaran, Penyusunan RPP, Diklat Teknis Substantif Penyusunan Bahan Ajar, Pendekatan Saintifik dalam Pembelajaran, dan Pengelolaan Penilaian Pembelajaran. Guru-guru merasa diklat ini sangat penting dilakukan karena mereka merasa kompetensi 
mereka masih harus perlu ditingkatkan dalam hal merencanakan, melaksanakan dan mengevaluasi pembelajaran. Guru juga sangat membutuhkan diklat PKG dan PKB, Penilaian Angka Kredit Guru, Publikasi Ilmiah, Karya Inovasi. Selain itu guru juga merasa sangat membutuhkan diberikan diklat yang dapat membekali guru dengan kemampuan penunjang lainnya seperti lainnya seperti kemampuan dalam membuat media pembelajaran yang interaktif. Diklat lainnya yang sangat dibutuhkan guru dalam menjalankan tugasnya yaitu, Diklat Teknis Substantif sesuai mata pelajaran yang diampu dan Diklat Teknis Substantif Ujian Nasional. Selain diklat untuk guru, diklat teknis substantif pendidikan yang juga dibutuhkan yaitu untuk pengembangan kompetensi Pengawas. Diklat tersebut diantaranya Diklat Teknis Substantif Supervisi Pengawas Pendidikan Agama dan Madrasah, Karya Tulis Ilmiah Pengawas Pendidikan Agama, Penilaian Angka Kredit Pengawas Pendidikan Agama dan Pengawas Madrasah. Dikat ini dibutuhkan untuk meningkatkan kompetensi pengawas dalam melaksanakan tugas pokoknya khususnya dalam menghasilkan karya tulis ilmiah dan mengenali berbagai jenis unsur untuk pemenuhan angka kredit untuk pengembangan profesi pengawas.

Selain Diklat Teknis Pendidikan, Balai Diklat Keagamaan Denpasar juga memprioritaskan pelaksanaan diklat teknis keagamaan. Beberapa diklat teknis keagamaan yang menjadi prioritas untuk dilaksanakan yaitu Diklat Penyuluh Agama Non PNS, Karya Ilmiah Penyuluh Agama dan Penilai Angka Kredit Penyuluh Agama. Diklat Teknis Substantif Penyuluh Agama Non PNS menjadi prioritas utama untuk dilaksanakan dari tiga jenis diklat terkait pengembangan kompetensi penyuluh yang disebutkan di atas. Hal ini sesuai dengan program pemerintah yang memberikan tugas kepada penyuluh agama non PNS sebagai prajurit terdepan yang menyuarakan kerukunan antarumat beragama di tengah keberagaman bangsa Indonesia. Diklat lain terkait kepenyuluhan yang akan dilaksanakan yaitu diklat Teknis Substantif Karya Ilmiah Penyuluh Agama dan Diklat Teknis Substantif Penilai Angka Kredit Penyuluh Agama. Diklat ini sangat diperlukan untuk meningkatkan kompetensi penyuluh dalam menghasilkan KTI dan mengidentifikasi unsur-unsur pemenuhan angka kredit untuk kenaikan pangkat dan jabatan penyuluh. Selain untuk penyuluh, pelaksanaan diklat teknis keagamaan yang dibutuhkan seperti Diklat Teknis Substantif Kerukunan Umat Beragama, Petugas Penyelenggara Haji, Pembina Kamasjidan dan Hisab Rukyat.

Diklat fungsional juga menjadi prioritas untuk dilaksanakan baik itu guru maupun pengawas. Diklat Fungsional untuk guru yang menjadi prioritas utama untuk 
dilaksanakan yaitu Diklat Fungsional Guru Muda, kemudian dilanjutkan dengan Diklat Fungsional Guru Madya dan Pertama. Hal ini dikarenakan banyak guru di lingkungan Kantor Kementerian Agama Provinsi Bali, Nusa Tenggara Barat dan Nusa Tenggara Timur yang berada pada golongannya III/c III/d dengan jenjang jabatan guru muda yang sangat memerlukan pengetahuan tentang kompetensi apa yang perlu ditingkatkan pada jenjang jabatan guru muda. Demikian juga untuk jabatan guru madya. Diklat prioritas lainnya yang dibutuhkan yaitu diklat fungsional guru dengan tugas tambahan tertentu seperti Diklat Fungsional Calon Kepala Madrasah dan Calon Kepala Laboratorium. Diklat fungsional untuk pengembangan kompetensi pengawas yang dibutuhkan yaitu Diklat Fungsional Calon Pengawas dan Diklat Fungsional Pengawas Utama.

Balai Diklat Kegamaan Denpasar juga mengagendakan pelaksanaan diklat Fungsional Keagamaan yang ditujukan untuk tenaga keagamaan seperti Penyuluh, Penghulu, Calon Penghulu dan Calon Kepala KUA. Diklat-diklat yang didapatkan dari hasil Analisis Kebutuhan Diklat ini, baik yang mencakup diklat teknis pendidikan maupun keagamaan akan dilaksanakan sesuai skala prioritas berdasarkan data AKD.

\section{E. PENUTUP}

\section{Simpulan}

Simpulan dari penelitian ini yaitu "Jenis diklat yang dibutuhkan untuk pengembangan kompetensi ASN di wilayah Kerja Balai Diklat Keagamaan Denpasar berdasarkan hasil Analisis Kebutuhan Diklat Tahun 2018, diperoleh hasil yaitu: (1) Diklat Substantif pendidikan sebesar 75,14\%, (2) Diklat Teknis Substantif Keagamaan sebesar 9,19\%, (3) Diklat Fungsional Pendidikan sebesar 11,85\% dan (4) Diklat Fungsional Keagamaan sebesar 4,32\%".

\section{Saran}

Agar hasil Analisis Kebutuhan Diklat (AKD) ditindaklanjuti oleh Balai Diklat Keagamaan Denpasar, yaitu menyelenggarakan program diklat Tahun 2019 dengan mempertimbangkan skala prioritas.

\section{DAFTAR PUSTAKA}

Barbazette, J. 2006. Training Needs Analysis; Methods, Tools and techniques. USA: Pfeiffer

Bee. 2006. Analisis Kebutuhan Diklat. Bandung: PKP2A I LAN

Hariandja, Marihot Tua. 2007. Manajemen Sumber Daya Manusia. Jakarta: Grasindo Jakarta

Kementerian Agama RI. 2015. Peraturan Menteri Agama No. 75 Tahun 2015 tentang Penyelenggaraan Pendidikan dan 
Pelatihan Pegawai pada Kementerian Agama. Jakarta

Mangkunegara. 2005. Manajemen Sumber Daya Manusia Perusahaan. Bandung: CV. Rosdakarya

Menzel K. \& Messina. 2011. Training Need Analysis (TNA). Sydney Australia: The Royal Australian dan New Zealand College of Radiologist

Papu. Johanes. 2002. Analisis Kebutuhan Pelatihan. Jakarta: Grasindo Jakarta

Presiden Republik Indonesia. 2000. Peraturan Pemerintah Republik
Indonesia No. 101 Tahun 2000 tentang Pendidikan dan Pelatihan Jabatan Pegawai Negeri Sipil

Tees, David W., You, Nicholas., dan Fisher, Fred., (1987). Manual For Training Needs Assessment In Human Settlements Organizations, A Systematic Approach To Assessing Training Needs. The United Nations Centre for Human Settlements 